\title{
Volcanic history of the Lower Tertiary plateau basalts in the Scoresby Sund region, East Greenland
}

\author{
W. S. Watt, L. M. Larsen and M. Watt
}

\begin{abstract}
The extensive plateau basalt lava pile in the Scoresby Sund region has a stratigraphic thickness of $3200 \mathrm{~m}$ and an overall average thickness of $1500 \mathrm{~m}$. The pile thins inland from the Atlantic coast and laps onto basement gneisses and Jurassic sediments in the inner fjord region. The lavas are divisible into five formations which form two separate lava sequences. The lower sequence is best developed in the inner fjord region, while the upper sequence dominates the regions near the Atlantic coast. The sequences are interpreted as produced in two volcanic episodes in connection with failed rifting episodes during the opening of the North Atlantic Ocean. At the Atlantic coast remains of a third separate lava sequence apparently formed during active spreading.
\end{abstract}

\section{Introduction}

Extensive areas in central East Greenland are covered with plateau basalts. These were erupted in Lower Tertiary time (Upper Paleocene - Lower Eocene) in connection with the initiation of sea-floor spreading and the formation of the North Atlantic Ocean. Large and small remnants of volcanic activity in the form of lava flows, dykes, sills and central intrusions are found along the Atlantic coast of East Greenland from $66^{\circ} \mathrm{N}$ (Angmagssalik) to $75^{\circ} \mathrm{N}$ (Shannon) (Deer, 1976; Noe-Nygaard, 1976). However, the largest area with coherent basalt cover is the region at $68^{\circ}-70^{\circ} \mathrm{N}$, beteen Kangerdlugssuaq and Scoresby Sund (fig. 1).

The basalts in the Scoresby Sund region were mapped during GGU expeditions to East Greenland in the years 1968-1972. The original programme only covered the area north of $70^{\circ} \mathrm{N}$, but since key areas to the basalt stratigraphy were found further south, mapping was subsequently extended south of $70^{\circ} \mathrm{N}$.

\section{General geology}

The map and cross-section (fig. 1) show the main structure of the basalt pile in the Scoresby Sund region. The basalts lap on to the elevated area in the north-west and their base drops below sea-level to the east. They are essentially flat-lying, with a regional dip of $\frac{1}{2}-1^{\circ}$ SE. A $10-30 \mathrm{~km}$ broad strip along the Atlantic coast is extensively block faulted with downthrows to the south-east in excess of $1500 \mathrm{~m}$. The faulted coastal area hosts a $200 \mathrm{~km}$ long swarm of coast-parallel basalt dykes while in the inland areas ENE-trending dykes occur over a broad region in Milne Land, Gåseland and south of Gåsefjord (fig. 2).

The aggregate thickness of the lava pile is $3200 \mathrm{~m}$. Actual thicknesses are greatest at the Atlantic coast and decrease inland to $1500 \mathrm{~m}$ around Gåsefjord and to $300-800 \mathrm{~m}$ on Gåseland and Milne Land. The overall average thickness is $1500 \mathrm{~m}$. All the basalts were extruded 

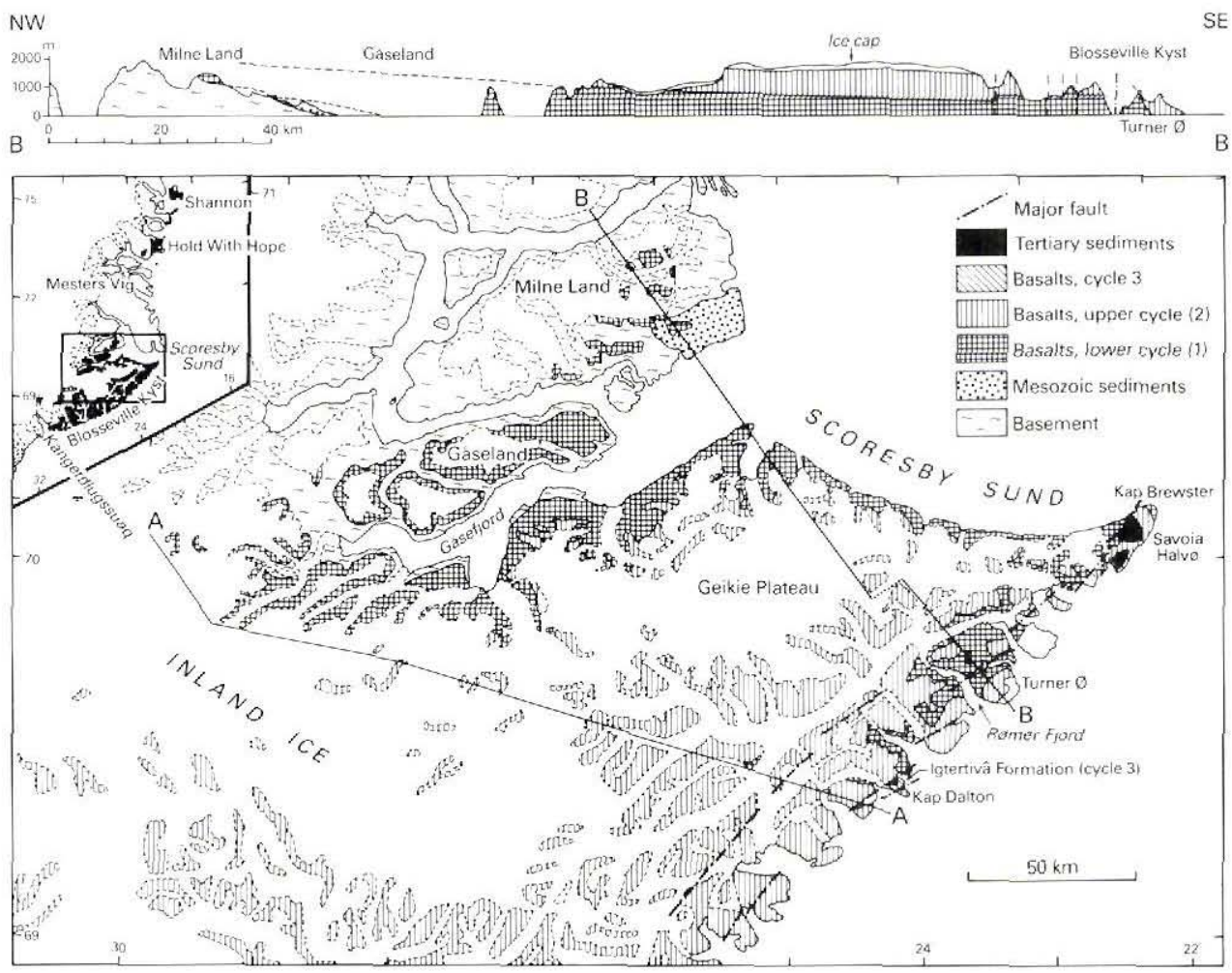

Fig. 1. The East Greenland plateau basalts between $69^{\circ} \mathrm{N}$ and Scoresby Sund. The area investigated in detail is that north of the line A-A, an area of approximately $24000 \mathrm{~km}^{2}$. South thereof reconnaissance work was made south to $69^{\circ} \mathrm{N}$. The generalised cross-section was made along the line $\mathrm{B}-\mathrm{B}$, with five times vertical exaggeration.

sub-aerially, and red, scoriaceous flow tops are common. Single lava flows are usually large, $10-50 \mathrm{~m}$ thick, with volumes ranging from a few cubic kilometres to at least $300 \mathrm{~km}^{3}$.

\section{Basalt stratigraphy}

Due to the dissected and partly glaciated character of the area, with many glacier tongues reaching from the highland plateaux down to the coast, single lava flows can usually only be followed laterally for short distances in the field, and marker horizons are conspicuously absent.

The basalts were mapped by detailed measuring and sampling of numerous profiles, and by correlation between these of characteristic properties, such as flow thicknesses and morphology, phenocryst content and mode, colour and weathering appearance, and, later, chemical composition. In this way characteristic flows and sequences of flows can be followed laterally over large areas.

Five basalt formations of regional extent have been established; the Magga, Milne Land, Geikie. Rømer Fjord and Skrænterne Formations. A sixth and youngest formation, the Ig- 


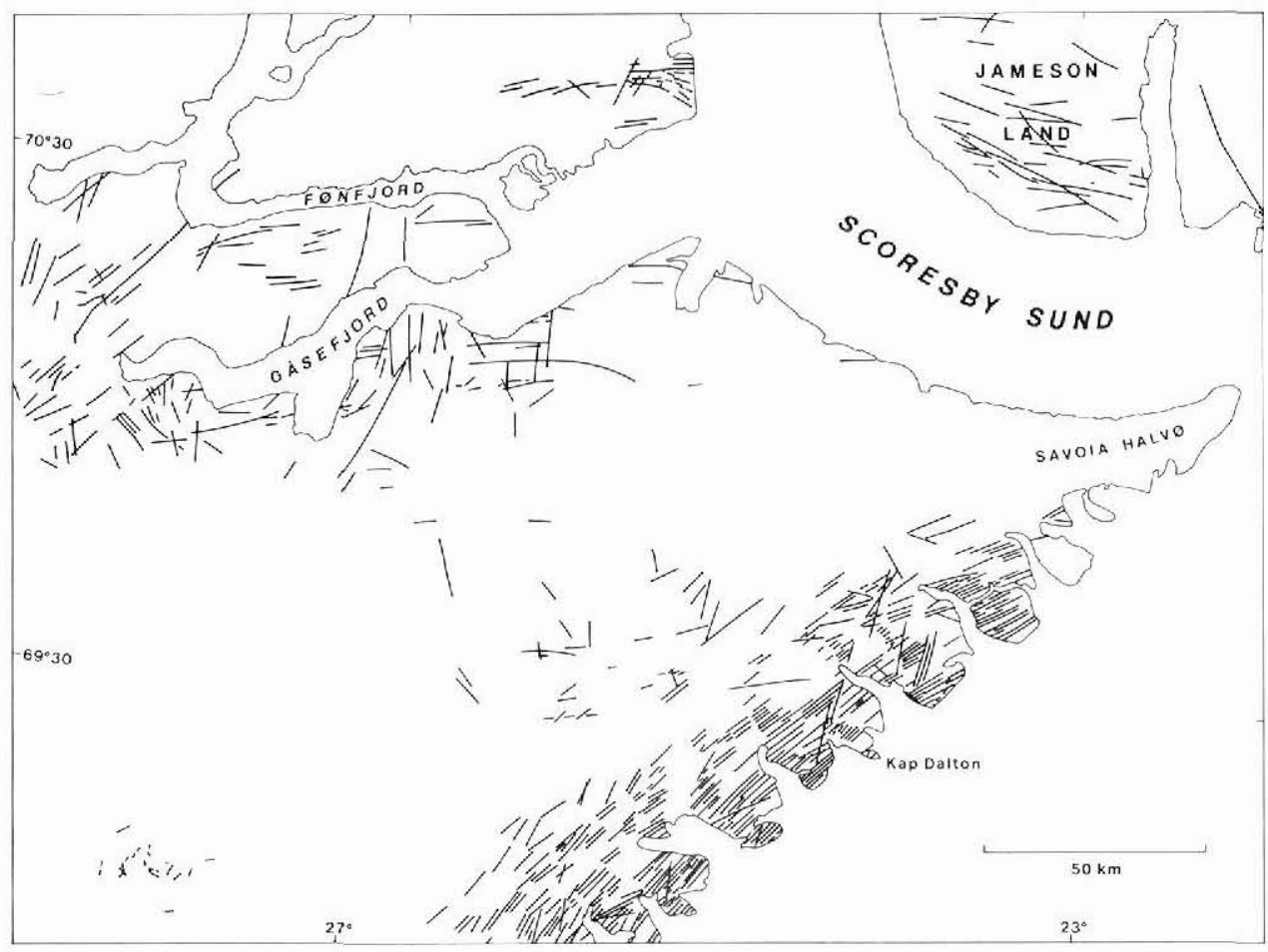

Fig. 2. The dyke pattern in the area covered by fig. 1. The distribution of the lavas and the ice cover appears from fig. 1. Although the ice cover disguises the details of the dyke pattern, the concentration of the dykes in two areas along the Atlantic coast and the inland regions around Gasefjord appears to be real.

tertivâ Formation, is only preserved as a down-faulted fragment at Kap Dalton. These formations are formalised by Watt et al. (unpublished) and their characteristics are summarised in fig. 3 .

The five regional basalt formations are all conformable. They form two separate lava sequences, the distribution of which is shown in fig. 1. The Igtertivâ Formation is regarded as a third separate sequence.

The two major basalt sequences show systematic compositional zoning. Fig. 3 shows some important compositional patterns within a composite profile through the complete lava sequence. The individuality of the various formations is seen in the alternation between compositionally heterogeneous and homogeneous formations. If the lowest formation (Magga) is excepted as an initial phase, the two major basalt sequences show very similar systematic development in composition with height: a phase with very variable eruption products (Milne Land/Rømer Fjord Formations) is succeeded by a monotonous phase (Geikie/ Skrænterne Formations) which shows systematic step-like decrease in $\mathrm{TiO}_{2}$ with height, and ends in a reversal to higher $\mathrm{TiO}_{2}$ contents. The step-like compositional patterns are found in all profiles through these formations, and they are thereby subdivided into units as indicated in fig. 3 . 
150
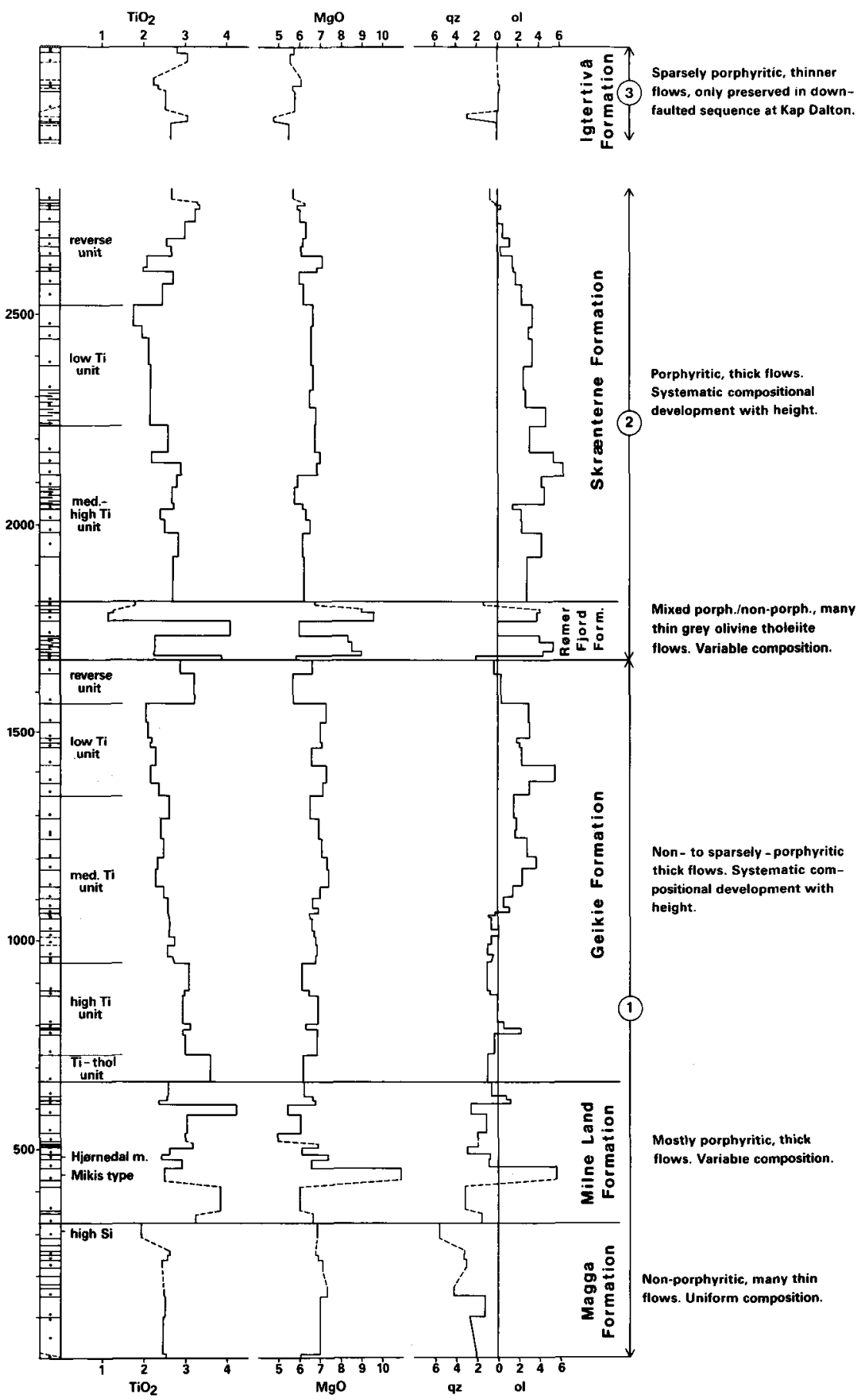

Fig. 3. Variations in chemistry, normative composition and characteristic features in a composite profile through the lava pile. The lava pile is sketched in the column to the left, with thicknesses given in metres; dots indicate sample positions. Broken lines on the curves indicate unsampled lava flows. The gap between the Skrænterne and Igtertivâ Formations indicates the lack of stratigraphic continuity due to faulting. The subdivision into formations is based on field critieria; the subdivision into units is based on the $\mathrm{TiO}_{2}$ profile. The ringed digits indicate the three sequences discussed in the text. 
Each of the two major basalt sequences are interpreted as having been produced in a cyclic episode of volcanic activity (Larsen \& Watt, 1985). At the beginning of each cycle the situation was unstable and a variety of both strongly and less differentiated magma types were produced. Then the situation apparently stabilised and the basalts became more uniform and systematically less differentiated with height, signalling increasing volcanic activity and shorter residence times in the magma chambers. The low-Ti units formed at the peak of activity, and the uppermost, 'reverse' units in each sequence formed when the activity waned and died. The two volcanic cycles are viewed as produced in two temporary rifting episodes, while the third sequence is part of the products from a third rifting episode. These episodes can be related to events during the opening of the North Atlantic Ocean.

\section{The substratum of the basalts}

During Mesozoic time a N-S elongated sedimentary basin developed in East Greenland, partly bounded by faults towards the Caledonian and older highlying crystalline basement to the west (Surlyk et al., 1981). Sediments of this basin occupy extensive areas in Jameson Land, immediately to the north of the basalts, and are also found on Milne Land where they are partly covered by basalts (fig. 1). A small exposure of Cretaceous sediments is found below the basalts on the south side of Scoresby Sund at Kap Brewster (R. A. Fensome in Watt \& Watt, 1983), but the extension of the sedimentary basin to the south, below the basalts, is unknown. Cretaceous sediments underlie the basalts at Kangerdlugssuaq (Deer, 1976; Nielsen et al., 1981) $400 \mathrm{~km}$ to the south, and it is believed that the sedimentary basin is continuous and underlies the whole eastern half of the lava pile. This concept is supported by the occurrence of methane, presumably sediment-derived, in the warm springs issuing from the lavas at Rømer Fjord on the Blosseville Kyst, and the occurrence of migrated hydrocarbons in the lavas at Savoia Halvø (Watt \& Wrang, 1984).

At the onset of volcanism, the landscape thus consisted of two very different elements: a flat, low-lying sedimentary plain in the east and south-east, and in the west and north-west a mountainous gneiss country with deeply incised valleys leading down to the plain. The mountains and valleys have been preserved beneath the basalt cover, and where this has been removed by later erosion, the old landscape elements have reappeared. Thus, Gåseland as a mountain ridge and Gåsefjord as a valley are elements of Paleocene age.

One of the main boundary faults between the highland and the plain runs approximately NNE-SSW through the eastern part of Milne Land. It cannot be followed farther south.

\section{First volcanic episode}

\section{Magga Formation}

The volcanism started in the inland region around Gåsefjord. Here, the Magga Formation occurs as an up to $300 \mathrm{~m}$ thick sequence of thin, aphyric, grey-brown flows and flow units (fig. 4). Most of these lavas were confined to the lowland areas, but some lavas were apparently erupted from local vents in the high-lying areas of Gaseland. Pillow breccias are frequent in this formation; they formed where the lavas inundated moist valley bottoms and river beds and dammed up the rivers.

The formation is compositionally uniform and consists of moderately differentiated ba- 


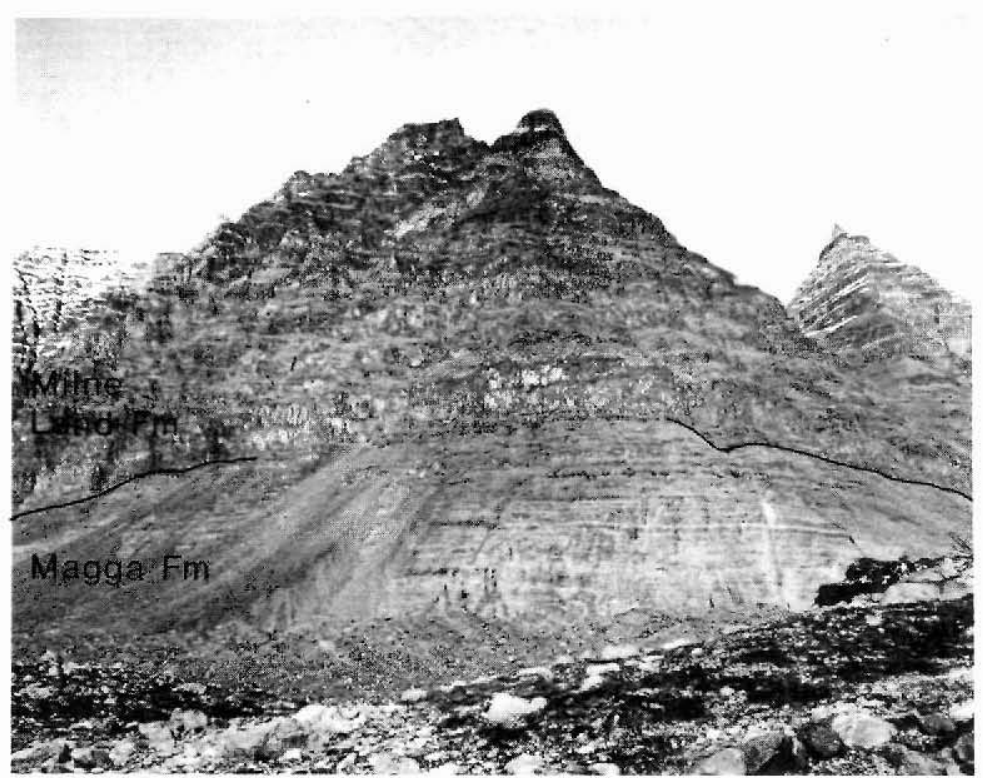

Fig. 4. The Magga and Milne Land Formations on the south side of Gåsefjord. The Magga Formation forms the lower third of the profile, comprising thin, partly scree-covered flows.

salts. These are all quartz normative (fig. 3 ) and have higher silica contents than the succeeding basalts. They are believed to have been contaminated with continental crust during the formation of the first magma chambers in the crust.

\section{Milne Land Formation}

This formation is up to $350 \mathrm{~m}$ thick and consists of thicker, trap-forming flows of mostly feldspar-phyric basalt (fig. 4). Many flows have very well-developed colonnades (Noe-Nygaard, 1976, fig. 342). The lower boundary of the formation is irregular due to the irregular substratum. and pillow breccias still formed in valley bottoms and lakes. During the build-up of this formation, the lavas completely engulfed and overflowed the old Gaseland mountain ridge and spread to the west and north. One of the first lava flows to do so was the voluminous Hjørnedal marker flow which is both petrographically and compositionally distinctive and has been found in all profiles which cover the appropriate stratigraphic level. This flow covers a minimum area of $11500 \mathrm{~km}^{2}$ and has a minimum volume of $285 \mathrm{~km}^{3}$; like the other flows in this formation, its extension towards the east and south-east cannot be delimited because it drops below sea-level. Extrusion sites for this formation are not known but are believed to be centred in the Gasefjord area.

Compositionally, the formation is heterogeneous. It includes a flow of $\mathrm{Mg}$-rich basalt compositionally similar to the basalts of the Mikis Formation in the lower basalts in Kangerdlugssuaq (Nielsen et al., 1981), and also includes the first Ti-rich, strongly differentiated basalts. One of these Ti-rich flows has a calculated minimum volume of $300 \mathrm{~km}^{3}$, and the development of such a large volume of strongly differentiated basalt requires that great magma 
chambers must by then have come into existence. The occasional presence of high-Si flows shows that wall rock contamination still took place intermittently. Most lavas are still quartz normative (fig. 3), probably a long-term effect of this contamination.

\section{Geikie Formation}

This is the most voluminous and widespread basalt formation. It is up to $1100 \mathrm{~m}$ thick and consists of thick, trap-forming flows of aphyric or sparsely porphyritic basalt with a clear division in many flows into a lower colonnade and an upper entablature. The lavas of this formation spread out over the level basalt plain from east to west and overstepped further the gneiss highland on Milne Land. The inland dykes on Milne Land, Gåseland and south of Gåsefjord-Scoresby Sund (fig. 2) are compositionally identical to the lavas of the Geikie Formation, and are believed to be feeders for this formation. The whole first volcanic episode thus seems to be centred in the inland region around Gasefjord.

Compositionally, the Geikie Formation can be subdivided into five units (fig. 3) which are not mappable in the field but can be recognised in all analysed profiles. As interpreted by Larsen \& Watt (1985), during the build-up of this formation magma input into the crustal magma chambers increased, leading to shorter residence times in the magma chambers and eruption of successively less differentiated lavas. The activity culminated with the formation of low-Ti basalts, similar in many respects to those formed at mid-ocean ridges. However, the incipient rifting failed and the magma chambers died with the formation of the fractionated basalts in the uppermost 'reverse' unit.

The long-term effects of crustal contamination appear to have gradually worn off during the build-up of the Geikie Formation, such that basalts changed their character from quartz to olivine normative (fig. 3 ).

\section{Second volcanic episode}

After a hiatus and local sediment accumulation, especially in the eastern areas, volcanic activity started anew. The activity was displaced to the south-east relative to that of the first episode, and both the following two formations thin inland from the Atlantic coast, and probably never reached north-west of Gảsefjord (fig. 1).

\section{Rømer Fjord Formation}

This formation is up to $250 \mathrm{~m}$ thick and often forms a recessive bench on top of the Geikie Formation (fig. 5). It is characteristically mixed and contains sequences of thin, grey compound flows of aphyric $\mathrm{Mg}$-rich basalts intercalated with sequences of strongly differentiated and highly porphyritic 'big feldspar' basalts. The $\mathrm{Mg}$-rich basalts in particular are rich in zeolites which contribute to the grey colour of the lavas.

Individual lava volumes in this formation are small and some of the sequences form shieldlike structures which were probably erupted in different local areas. Judged from thickness variations in individual sequences, the major eruption sites appear to have been around the present Atlantic coast, with minor eruption sites scattered in inland areas around the Geikie Plateau. At this time magma chambers were apparently small and widespread, and there are no signs of crustal contamination of any lavas.

Of local origin is a nephelinitic ash layer found in the northern part of the Geikie Plateau, where it covers an area of around $20 \mathrm{~km}^{2}$ and is up to $12 \mathrm{~m}$ thick. The vent for this violently 

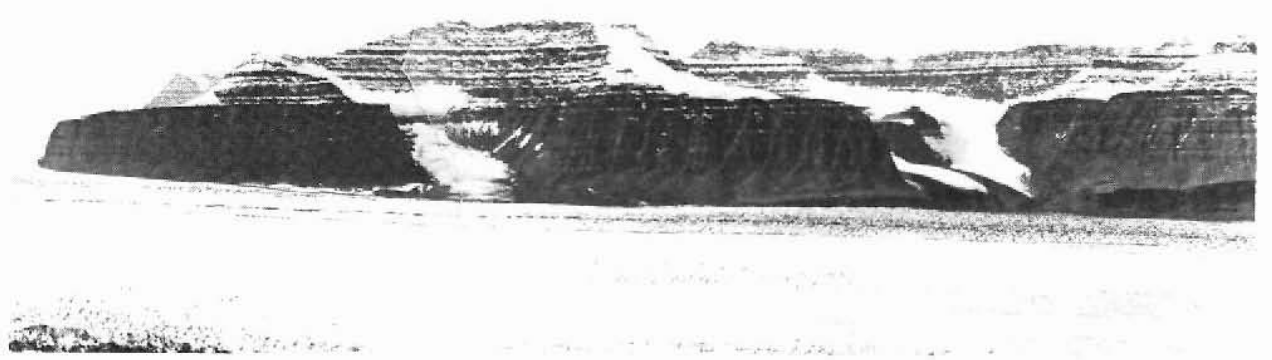

Fig. 5. A cliff section south of Gassefjord. The lower half of the section comprises lavas of the Geikie Formation. On top of this the thin recessive Rømer Fjord Formation leaves a marked bench and is overlain by partly snow-covered lavas of the Skrænterne Formation.

explosive eruption must have been situated within the confines of the ash layer. Compositionally strongly contrasting magmas were thus erupted side by side in this formation, and different magma reservoirs must have been tapped.

\section{Skranterne Formation}

This formation is thick and voluminous like the Geikie Formation. but not so extensive. It is up to $1000 \mathrm{~m}$ thick and consists of thick, voluminous, trap-forming flows (fig. 5) of porphyritic basalt in which the phenocrysts characteristically are lumped together in small tight clusters. The formation is divisible into three units, of which the lower two reach $100-150 \mathrm{~km}$ inland from the Atlantic coast and both thin towards the inland areas. while the upper unit is conlined to within $60 \mathrm{~km}$ from the coast. The volcanism thus appears to have contracted towards the coast with time. No dykes which could have fed the lavas of this formation have been found, and the eruption sites are inferred to be east of the present coast. If the lavas were symmetrically disposed around the eruption centres, this implies that more than half the original volume of this formation has subsequently been removed by the opening of the North Atlantic Ocean because the ocean-to-continent transition zone is situated $10-25 \mathrm{~km}$ east of the present coast (Larsen, 1984).

The three units of the Skrænterne Formation are defined compositionally and are interpreted as signifying increasing, culminating and decreasing volcanic activity (fig. 3; Larsen \& Watt, 1985). The low-Ti basalts produced during the peak period constitute a larger proportion of this episode than of the first. The activity of the second episode was thus more intensive than the first. but the second episode also failed and the activity died.

Although the lavas of this formation are generally olivine normative (fig. 3). the presence of two flows of Si-rich basalt indicates that crustal contamination took place occasionally.

\section{Third volcanic episode}

\section{Igtertivâ Formation and coastal dyke swarm}

After the two volcanic episodes which led to the formation of the two regional basalt sequences, a third episode took place which was narrowly confined to the present Atlantic 

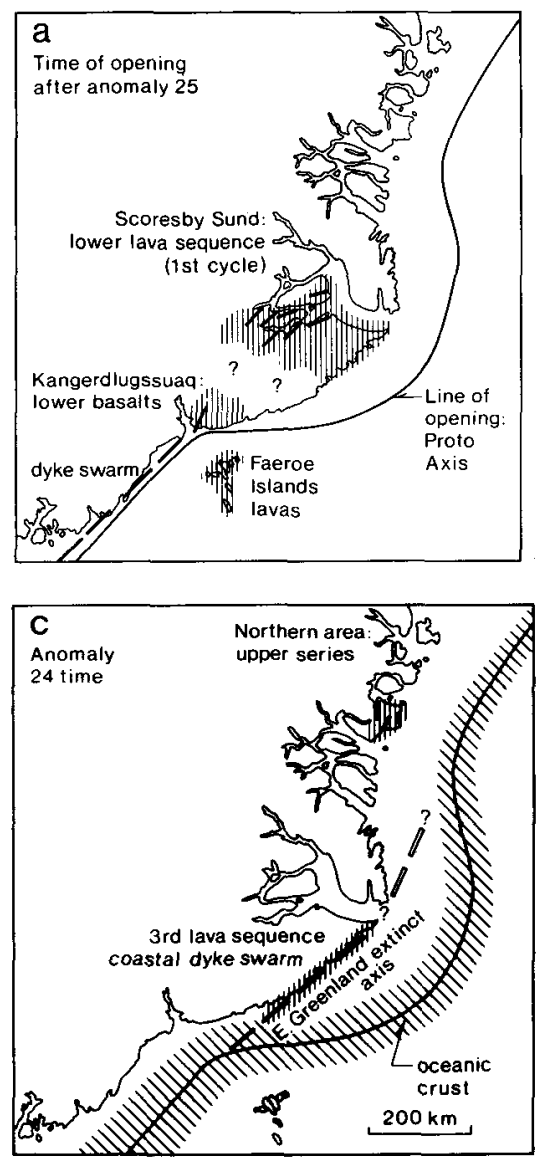

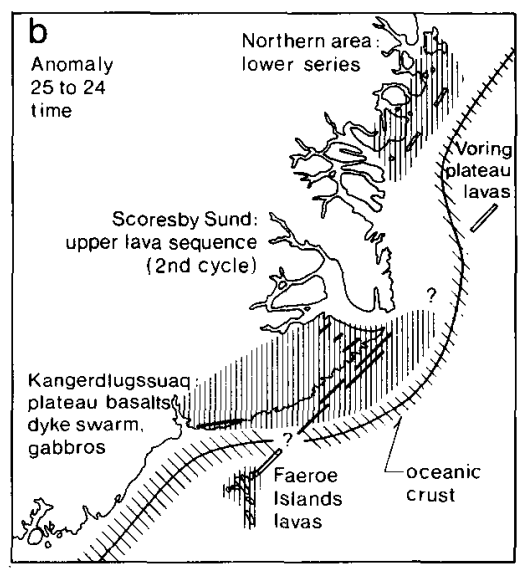

Fig. 6. The three volcanic episodes during the continental break-up of the North Atlantic between anomalies 25 and 24. Basalts are shown with vertical ruling, extrusion sites by heavy lines, open where extrapolated. The tentative correlations between the basalts in the northern area, Scoresby Sund and Kangerdlugssuaq fit the available field, geochemical and palaeomagnetic evidence. Ocean spreading pattern after Larsen (unpublished manuscript, 1985).

coast. Rifting and faulting fragmented the coastal zone and an intense coast-parallel dyke swarm was intruded (fig. 2). The Igtertivâ Formation lavas, now only preserved in a $400 \mathrm{~m}$ thick down-faulted sequence at Kap Dalton, were apparently fed by this dyke swarm. The lavas are not cut by these dykes and are compositionally very similar to them. The lavas were probably always confined to the faulted zone. They are overlain by fossiliferous marine sediments of Lower Eocene age, and some of the faulting is younger than this (Soper \& Costa, 1976).

The lavas and dykes of this episode exhibit a contrast in some important element ratios $(\mathrm{Ti} / \mathrm{P}, \mathrm{Zr} / \mathrm{Nb}$ ) compared to those of the earlier lavas and dykes. Their overall composition and their element ratios are similar to those of basalts formed at actively spreading ridges on Iceland and at the Mid-Atlantic Ridge (e.g. Jakobsson, 1979; Schilling et al., 1983; Larsen \& Watt, 1985), and judged from the chemical compositions it appears that the third rifting episode, in contrast to the two preceding ones, did produce spreading.

\section{Relations to sea-floor spreading}

It is generally agreed that the East Greenland Tertiary lavas were erupted during the period of 3 million years between geomagnetic anomalies 25 and 24, approximately 53-56 
m.y. ago (Faller, 1975; Soper et al., 1976). At the same time, sea-floor spreading with opening of the North Atlantic Ocean was initiated in the region. The spreading process was very complicated in this region, and the first spreading axis had a winding course with considerable eastwards displacement in the region considered here (fig. 6; Larsen, unpublished manuscript, 1985). The two first magmatic episodes deciphered in the Scoresby Sund basalts apparently represent failed attempts to short-cut the eastwards displacement of the spreading axis, while the third episode is connected with the short-lived East Greenland extinct axis (fig. 6c) and was successful in so far as it produced a narrow strip of oceanic crust (Larsen, unpublished manuscript, 1985) and lavas with the geochemical imprint of active spreading.

\section{References}

Deer, W. A. 1976: Tertiary igneous rocks between Scoresby Sund and Kap Gustav Holm, East Greenland. In Escher, A. \& Watt, W. S. (edit.) Geology of Greenland, 304-339. Copenhagen: Geol. Surv. Greenland.

Faller, A. M. 1975: Palaeomagnetism of the oldest Tertiary basalts in the Kangerdlugssuaq area of East Greenland. Bull. geol. Soc. Denmark 24, 173-178.

Jakobsson, S. P. 1979: Petrology of recent basalts of the eastern volcanic zone, Iceland. Acta Nat. Islandica 26, $103 \mathrm{pp}$.

Larsen, H. C. 1984: Geology of the East Greenland Shelf. In Norwegian Petroleum Society (edit.) Petroleum geology of the North European Margin, 329-339. London: Graham \& Trotman.

Larsen, H. C.: A new rift model for the central NE Atlantic. Unpublished manuscript, 1985.

Larsen, L. M. \& Watt, W. S. 1985: Episodic volcanism during break-up of the North Atlantic: evidence from the East Greenland plateau basalts. Earth planet Sci. Lett. 73, 105-116.

Nielsen, T. F. D., Soper, N. J., Brooks, C. K., Faller, A. M., Higgins, A. C. \& Matthews, D. W. 1981: The pre-basaltic sediments and the Lower Basalts at Kangerdlugssuaq, East Greenland: their stratigraphy, lithology, palaeomagnetism and petrology. Meddr Grønland, Geosci. 6, 25 pp.

Noe-Nygaard, A. 1976: Tertiary igneous rocks between Shannon and Scoresby Sund, East Greenland. In Escher, A. \& Watt, W.S. (edit.) Geology of Greenland, 304-339. Copenhagen: Geol. Surv. Greenland.

Schilling, J.-G., Zajac, M., Evans, R., Johnston, T., White, W., Devine, J. D. \& Kingsley, R. 1983: Petrological and geochemical variations along the Mid-Atlantic Ridge from $29^{\circ} \mathrm{N}$ to $73^{\circ} \mathrm{N}$. Amer. J. Sci. 283, 510-586.

Soper, N. J. \& Costa, L. I. 1976: Palynological evidence for the age of Tertiary basalts and post-basaltic sediments at Kap Dalton, central East Greenland. Rapp. Grønlands geol. Unders. 80, 123-127.

Soper, N. J., Higgins, A. C., Downie, C., Matthews, D. W. \& Brown, P. E. 1976: Late Cretaceous early Tertiary stratigraphy of the Kangerdlugssuaq area, East Greenland, and the age of opening of the north-east Atlantic. J. geol. Soc. Lond. 132, 85-104.

Surlyk, F., Clemmensen, L. B. \& Larsen, H. C. 1981: Post-Paleozoic evolution of the East Greenland continental margin. Mem. Can. Soc. Petrol. Geol. 7, 611-645.

Watt, S. \& Watt, M. 1983: Stratigraphy of the basalts of Savoia Halvø, central East Greenland. Rapp. Grønlands geol. Unders. 115, 83-88.

Watt, W. S. \& Wrang, P. 1984: Migrated hydrocarbons in basalt on the south side of Scoresby Sund. Rapp. Grønlands geol. Unders. 120, 84-85. 